Peer Reviewed, pre-proof, pre-publication draft version. Subsequently published in The European Journal of Probation 2012 4(1): 84-98.

\title{
The Failure of Recall to Prison: Early Release, Front-Door and Back-Door Sentencing and the Revolving Prison Door in Scotland
}

\section{By Beth Weaver ${ }^{1}$, Cyrus Tata $^{2}$, Mary Munro ${ }^{3}$, Monica Barry ${ }^{4}$}

\begin{abstract}
This article seeks to explain the reasons for the sharp rise in prison recall rates in Scotland. It argues that recall practices need to be understood not as a technical corner of the justice system, but as part of a wider analysis of the politics of sentencing and release policy. While there are sound reasons for a policy of 'early release' (incentivizing good behavior and enabling the resettlement of prisoners), in practice early release has increasingly been used as a tool to try to limit the growth in the custodial population. Unable to control prison numbers through the front door' (judicial sentencing and bail/remand), successive governments have increasingly relied on early release as a surreptitious way of, in effect, re-sentencing prisoners. We argue that this political strategy is ultimately self-defeating, not least in feeding public cynicism about the penal system and community supervision in particular. This article reviews the changing legislative, policy and practice landscape of the regulation of non-compliance and recall practice, and draws on the desistance literature to illustrate how offender-supervisor relationships can be undermined by recall policies which threaten the legitimacy of both the supervisory relationship and the conditions of supervision orders.
\end{abstract}

Keywords: compliance - custody - desistance - early release - parole - recall - remission sentencing

1 Glasgow School of Social Work \& Centre for Law, Crime \& Justice, School of Applied Social Sciences, Strathclyde University, Scotland. E: Elizabeth.fawcett@strath.ac.uk

2 Centre for Law, Crime \& Justice, Law School, Strathclyde University, Scotland. E: Cyrus.Tata@ strath.ac.uk

3 Centre for Law, Crime \& Justice, Law School, Strathclyde University, Scotland. E: munro@cjscotland.org.uk

4 Centre for Law, Crime \& Justice, Law School, Strathclyde University, Scotland. E: Monica.Barry@ strath.ac.uk 


\section{Introduction}

While much academic focus has in recent years been on entry into prison following an initial custodial sentence, relatively scant attention has been paid to the practice of recall, which is sometimes seen as a discrete matter of law and technicality - an isolated corner of the penal system. This is somewhat curious since as Padfield and Maruna put it "'back door' release decisions can have as much influence as 'front door' sentencing practices in terms of sentence length and maintaining overall prison populations" (Padfield and Maruna 2006: 330). Rather than seeing recall as a technical matter separate from sentencing policy and practice, we argue that it is vital to understand 'early release', recall policy and legislation, and changes in breach practice as an integral part of the wider context of the politics of sentencing. While cogent arguments can be made for the 'early' release of prisoners (eg in terms of good order within prisons and the resettlement of ex-prisoners), we argue that release on licence and subsequent recall are also forms of $r e$-sentencing. They are decisions about the lessening or tightening of punishment under certain conditions and the fact that they may not take place in front of a judge nor in a courtroom is, in that sense, incidental (Arnott 2007). Although release and recall are formally labeled as 'administrative' procedures, judicial ('front-door') sentencing and ('back-door') release decision-making are both moments in which the extent and character of punishment is decided and in that sense both may be seen as forms of sentencing (Tata 2010: 196).

This article firstly outlines the legislative context underpinning the phenomena of recall and its rationale, in reference to the kaleidoscope of pertinent criminal and civil orders. By looking at the national criminal justice system of Scotland, the rise, and rising concern, in the rate of imprisonment as a consequence of recall in Scotland is conceptualised as a process of $r e$-sentencing though the prison 'back-door'. The argument advanced here is that this 'back-door' approach fails 
Peer Reviewed, pre-proof, pre-publication draft version. Subsequently published in The European Journal of Probation 2012 4(1): 84-98.

to reduce crime, fails to alleviate and may in fact only increase prison overcrowding, exacerbates re-offending, is incompatible with the 'rehabilitation ideal' and fails to address the root causes of non-compliance amongst those on licence. Explanations for the increase in recall are offered in reference to shifts in the regulation of offender compliance and shifts in the regulation and governance of practice in the implementation of this policy by front-line practitioners. Finally, this article draws on the desistance literature to explore the wider impact of recall policy and practice in Scotland. First, however, it is essential to sketch out briefly and simply the Scottish system of release and recall.

\section{A review of licence and recall law in Scotland}

The origins of remission of sentence before the conclusion of a custodial sentence lie in the era of transportation when a 'ticket of leave' from the colonies could be granted to offenders for good behavior (Thomson 2007). However, remission of prison sentences could also be traced to military manpower shortages in the First World War. The practice of granting remission persisted during peacetime and by 1952 was incorporated into Scottish Prison Rules as being an entitlement to unconditional release (McManus 1999).

As in England and Wales, a system of parole was introduced in Scotland following the Criminal Justice Act 1967, offering discretionary conditional early release following one third of a sentence of over 18 months. McManus (1999) argues that the politicisation of parole may be traced to the then Home Secretary's 1984 Conservative Party Conference announcement that parole would be restricted to prisoners serving five years and over. Against a background of continuing criticism of

5 Although a constituent part of the United Kingdom of Great Britain and Northern Ireland, Scotland has always been a separate legal system, especially in matters of criminal law and justice. In short it makes little sense to talk of British penal policy or UK sentencing. In terms of recall there are several important differences between the two national jurisdictions of England and Wales and Scotland, including sentencing policy, the supervision of offenders, and of course the law itself (see further Tata 2010). 
this reform, not least from the Parole Board of Scotland, review committees were set up in 1987 in both jurisdictions to look again at the question of early release. The Kincraig Committee (1989), reporting on Parole and related issues in Scotland based its recommendations on questions of public safety and the risk of re-offending rather than sentencing policy which had been excluded from its remit (McManus 1999). This failure to tackle front-door judicial sentencing and back-door release decision-making together as part of an integrated strategy was an early mistake which governments have since repeated, preferring to portray release policy as a discrete, technical matter. The result has been a system which is increasingly incoherent, anomalous, labyrinthine in its complexity, and ultimately self-defeating.

The Kincraig recommendations were carried forward, in principle if not in detail, by the Prisoners and Criminal Proceedings (Scotland) Act 1993 which, inter alia, drew a basic distinction between 'short-term' and 'long-term' prisoners. Short-term prisoners, i.e., those sentenced to a determinate sentence of less than four years, are in effect released automatically and unconditionally after half their sentence. However, an exception to the automatic and unconditional early release of shortterm prisoners is those convicted of a sexual offence for whom different provisions apply. Longterm prisoners, i.e., those sentenced to a determinate sentence of more than four years can be eligible for release on licence at the half-way point should the Parole Board so direct, and should be released on non-parole licence after two thirds of their sentence has elapsed. In both cases, the former prisoner, if breached, could be subject to recall. In Scotland, supervision of prisoners released in the community is conducted by Criminal Justice Social Workers (CJSWs). Importantly, they are employed by local authorities and work within wider social work departments rather than (as in England and Wales for instance) as part of a centralized 'offender management' authority.

Since 2006, the prison authorities have exercised powers of early release in the form of Home Detention Curfew orders (HDCs) (sect. 15 (5) Management of Offenders (Scotland) Act 2005). 
Peer Reviewed, pre-proof, pre-publication draft version. Subsequently published in The European Journal of Probation 2012 4(1): 84-98.

Short-term sentence prisoners considered to be low risk and serving sentences of between 3 and 12 months are eligible for HDC, which are enforced by electronic monitoring ('tagging') and are supervised under contract by a private monitoring company. The power to release on HDC at the one-quarter stage of a prison sentence is widely resented by judicial sentencers, prison staff and many practitioners. Revealingly, the recent Scottish Prisons Commission's (2008) recommendation to abolish the HDC in 2008 has not been implemented by the Scottish Government. Since 2008, electronic monitoring may also be imposed as a condition of parole.

Both long and short term prisoners may be punitively recalled by the judge as part of a subsequent sentence if they are convicted of an imprisonable offence during the unexpired period of the original sentence (Prisoners and Criminal Proceedings (Scotland) Act 1993, s.16), although it is not known how often this power is exercised.

In addition, the sentencing court at the point of sentence can seek to impose control and supervision of offenders on release from custody, in the following ways:

A. Extended sentences can be imposed:

(i) on an offender who is convicted of a relevant sexual offence, (or one which discloses a significant sexual aspect to the offender's behavior), where the offender would, but for the extended sentence, receive a determinate sentence of imprisonment of any length, or, (ii) on an offender who is convicted of any violent offence in circumstances where the offender would, but for the extended sentence, receive a sentence of 4 years or more. The duration of the extension to the sentence is determined by the court's opinion of the need to protect the public from serious harm, and can be up to 5 years for a violent offence and up to 10 years for a sexual offence, but not for a period in excess of the statutory maximum for 
that offence (Crime and Disorder Act, 1998, amending the Criminal Procedure (Scotland) Act, 1995).

B. Supervised Release Orders may be imposed where the court considers it necessary to protect the public from serious harm from offenders on release from a short sentence (between 12 months and four years). The order may be no longer than 12 months after the date of the prisoner's release, or an equivalent of half the sentence, whichever is shorter. Breach of the Order is referred to the sentencing court in the first instance by the supervising criminal justice social worker (Criminal Procedure (Scotland) Act, 1995).

C. Short Term Sex Offender Licences can be imposed on offenders convicted of sexual offences since 2006, following short determinate sentences (between six months and four years), and such licences preclude unconditional release. Such licencees may be subject to recall following failure to comply (Management of Offenders (Scotland) Act, 2005).

D. Orders for Lifelong Restriction have, since 2006, been imposed at the time of sentence in High Court cases where offenders are assessed as likely to pose a serious danger to the public. This in effect allows the court to impose an indeterminate life sentence in exceptional circumstances for an offence that would not otherwise attract such a sentence. (Criminal Justice (Scotland) Act, 2003).

E. Life sentences are only mandatory on conviction for murder. In these cases the sentencing court will make an order defining the 'punishment part' of the sentence which must be served in prison. When the 'punishment part' is completed the prisoner will be referred to the Parole Board to hold a life-prisoner tribunal, a private hearing which hears evidence from both executive branch of the state and the prisoner (who may be represented). The decision of the tribunal whether to release an 
Peer Reviewed, pre-proof, pre-publication draft version. Subsequently published in The European Journal of Probation 2012 4(1): 84-98.

individual on life licence is binding on both the prisoner and the prison authorities but may be subject to judicial review (Thomson 2010).

While this brief overview of the legal landscape illustrates the proliferation of conditional release orders now operating in Scotland, the mere presence of these orders cannot account for the dramatic increase in recall rates that the Scottish prison estate has witnessed over the past decade and to which we now turn.

The dramatic rise in recalled prisoners in Scotland

Before 1998, the average daily population of persons who had been recalled to Scottish prisons tended to remain under one per cent ( $2 \%$ of sentenced prisoners), whereas in 2010/11, the proportion of the average daily population on recall accounted for approximately 9 per cent (11\% of sentenced prisoners). Chart 1 shows this marked increase in the recall population in Scottish prisons in real terms. Whilst in 1998 , the average daily prison population on recall was 70 , by $2010 / 11$ this increased to 682 . This rise represents an 875 per cent increase against an increase in the average daily sentenced population of 25 per cent and the total prison population (including remands) of 30 per cent over the same period.

Chart 1: Average daily population in Scottish prisons 1986 - 2010/11 of sentenced and recalled prisoners 


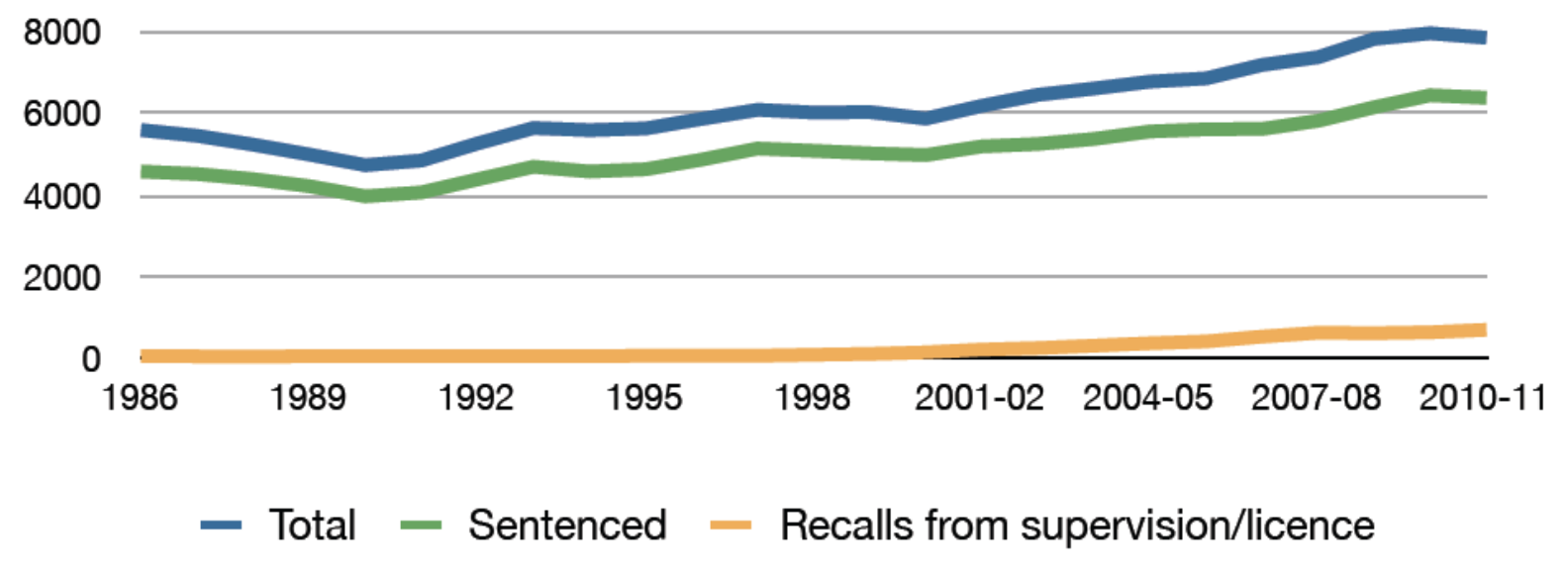

Source: Scottish Government Statistical Bulletins. Prison statistics series.

Charts 2 and 3 compare data derived from the Parole Board Annual Reports of 2003 and 2010/11 of all referrals to the Parole Board and subsequent direct recalls to prison by Scottish Ministers. Across all licence categories, the Parole Board rejects cases of referral or recall in around 1 in 3 cases and either re-releases the prisoner or makes some other determination. 
Peer Reviewed, pre-proof, pre-publication draft version. Subsequently published in The European Journal of Probation 2012 4(1): 84-98.

Chart 2: Profile of referrals and recalls in 2003

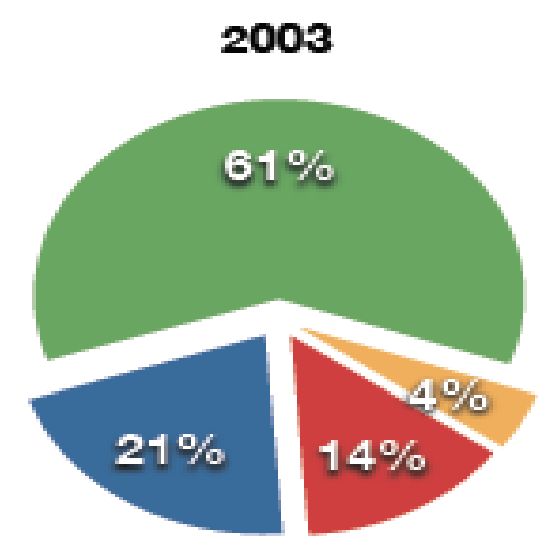

Parole licencees referrred Non-parole licencees referred / recalled Extended sentences Lifers referred (including immediate recall)

Total referrals/recalls $=\mathbf{3} 39$

Source: Parole Board for Scotland Annual Reports

Chart 3: Profile of referrals and recalls in 2009/10

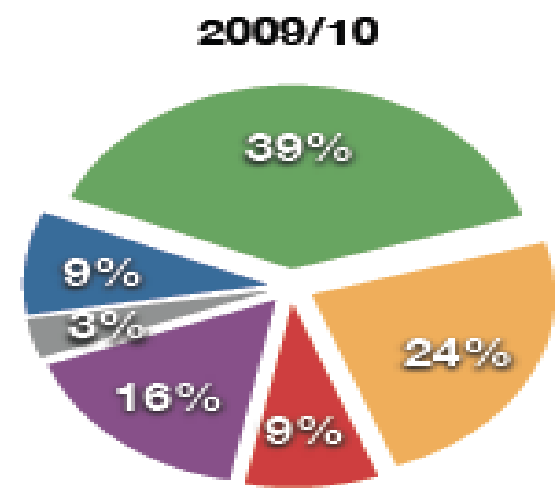

Parole licencees referrred Non-parole licencees referred / recalled Extended sentences

Lifers referred (including immediate recall) HDC

Short determinate sex offender licences

Total referrals/recalls $=496$

Source: Parole Board for Scotland Annual Reports 
The comparative figures in Charts 2 and 3 indicate that the more recent recall rates have a more complex profile than in 2003, not least because of the introduction of HDCs and short determinate sex offender licences in 2006. Nevertheless, both charts illustrate that the largest category of order referred was that of non-parole licence (longer term prisoners released at the two-thirds point), almost 2 in 5 in 2010/11. Nearly 1 in 5 of all referrals and recalls in 2010/11 (96 individuals) were for failure to comply with HDCs or short determinate sex offender licences. Referral and recall of parolees has shrunk from 23 per cent in 2003 to 9 per cent in 2010/11 (a drop from 71 to 44 individuals) and there has been a noticeable increase in the extended sentence category from 4 per cent in 2003 to 24 per cent of all recalls and referrals in 2010/11 (a rise from 15 to 119 individuals). Although life sentence prisoner recall rates have tended to be reasonably stable, at an average of around 44 per year in this period, as a proportion of all recalls, the lifer category has dropped from 14 per cent to 9 per cent.

We now seek to discuss ways in which the the rise in recall may be understood. In particular we focus on the need to consider the policy relationship between 'front door' and 'back door' sentencing and how its consequences are undermining the effectiveness of support and the ability of offenders to comply with conditions.

\section{Front door and back door sentencing}

As in other western countries, successive political administrations in Scotland have sought to use release as a means of controlling rises in the prison population. Unable to confront 'front door' sentencing policy so as to ensure a reduction in the use of imprisonment, release has been seen by successive political administrations as an expedient covert way of limiting the prison population without, it was hoped, attracting much media or judicial attention (Tata 2010). In this way, early 
Peer Reviewed, pre-proof, pre-publication draft version. Subsequently published in The European Journal of Probation 2012 4(1): 84-98.

release is not only a way of incentivizing good behavior in prison and enabling the resettlement of prisoners, but also reflects a surreptitious of cutting the length of custodial sentences: in other words it has largely a form of re-sentencing via the prison back-door. In other words, the principal purpose of release policy is now to cut judicially-imposed sentences under the guise of the principles of rehabilitation and prison management. However, we argue that this political strategy is ultimately self-defeating: the use of early release to cut real-time custodial sentences is now widely recognized for what it has become. Ironically, this surreptitious attempt to limit the rise in prison population is only further fuelling public cynicism about sentencing and punishment ${ }^{6}$ (see e.g., Anderson, et al., 2002; Roberts and Hough, 2005).

This strategy of surreptitious re-sentencing is most obvious in the case of short-term prisoners in Scotland who upon release receive no meaningful supervision, support or care. An illustration of the self-defeating nature of the use of early release and its impact on recall can be seen most recently in legislative attempts to make release appear more robust. As a response to the call for 'honesty' in sentencing, the Scottish Parliament passed legislation in 2007 which its supporters claimed would abolish automatic unconditional, unsupervised early release and replace it with 'combined' community and custodial sentences (Tata and Thomson 2011). All prisoners serving over 14 days would no longer simply leave prison at the half-way point (as in the case of those serving less than 4 years) or at the two thirds point (for those serving four years or more), but be subject to risk assessment, tough supervision, licence and recall if breached. However, the then Scottish Executive soon had to concede that, in the case of most short term prisoners, risk assessment and individualised supervision would simply not be achievable (Tata and Thomson 2011). For most short-term prisoners, the licence would be merely nominal (for example to 'be of good behaviour').

6 There is also the distinct possibility that at least some judges may at least sometimes inflate the headline sentences they pass so as to achieve the sort of 'effective' custodial sentence they think to be just. (See also on this point discussion by Ashworth 2005: 283-5) 
The 'tough, tailored' licences, which proponents of the Act promised at its passing, not only require much more funding but also more time to operationalise in the community: it is practically impossible to carry out proper risk assessment and individualised, 'tailored' supervision with people who have a few weeks of their sentence to go. In this way, we can see that despite the muchtrumpeted claim of transparency in sentencing and tough tailored supervision on licence, this is for most prisoners something of a fiction. Release could thus be seen as little more than a way of trying to control the rise in the prison population through back-door means because governments have felt unable to control it through front-door means (judicial sentencing, and the use of bail/remand). Inevitably, a public relations disaster for early release under this supposedly more rigorous release regime will ensue when a person who is released on (nominal) licence commits a heinous crime and responsibility and blame will be directed towards the professionals tasked with supervising those offenders. In this vein, judicial, media and public confidence in this approach, if deemed ineffective, is likely to further encourage risk averse practices and thus recall rates in a bid to restore credibility and external legitimacy. This only fuels public cynicism about release which in turn leads governments to make release conditions ever-more punitive and onerous, thus making their breach more likely. At the time of writing (end of 2011) this legislation had not been unimplemented and the future of release policy remains uncertain (see further Tata and Thomson 2011).

Walking on ice: is recall a safety net and for whom?

Although explanations for the rise in recall need are likely to be complex, as Padfield and Maruna imply, it seems rather fanciful to suppose that "that the behaviours of ex-prisoners have changed substantially over the last few years." (Padfield and Maruna 2006: 337). Clearly any explanation for the marked change in recall trends in Scotland from the turn of the millennium is likely to be complex and grounded not only in the attitudes and actions of offenders but also in the increasingly 
Peer Reviewed, pre-proof, pre-publication draft version. Subsequently published in The European Journal of Probation 2012 4(1): 84-98.

'punitive turn' in sentencing in this period (see, for example, Cavadino and Dignan, 2006). But a punitive turn equally has many dimensions, not least a focus on managerialist practice and a tendency towards risk aversion amongst supervising Criminal Justice Social Workers (CJSWs). CJSWs' remit and practice in relation to breach are also subject to revised National Outcomes and Standards (NOS) (Scottish Government, 2004). Perhaps ironically, the Parole Board noted in its Annual Report for 2003 that one explanation for the increase in referrals and recall could be improvements in the regulation and practice of criminal justice social work supervision:

The expansion of through-care is also offering an improved quality of service in the postrelease phase, and National Standards are ensuring greater consistency in the post-release reports being submitted to the Justice Department and, in appropriate cases, the Board. Indeed, this may be one of the factors which has led to the increase in the numbers of cases referred for consideration of recall over the last two years (Parole Board for Scotland, 2003: 4).

Whilst the Parole Board placed the impetus to increased recall practice on the training and guidance given to supervising social workers, the Scottish Consortium on Crime and Criminal Justice argued in 2009 that increased recall could also result from sentencers' lack of understanding of the supportive role of, for example, extended sentences and their greater use of such sentences as a punitive measure (SCCCJ 2009). The proliferation of conditional release orders for offenders seems to be making it increasingly difficult to comply with various disposals. Not only are the myriad orders and associated conditions confusing to offenders, but certain orders also carry significant risks to offenders themselves, described by one lifer as 'walking on ice' (McIvor and Barry, 2000). 
Increases in identified incidences of non-compliance and ensuing recall may also likely to reflect both a shift in the wider cultural arena within which criminal justice social workers practice (Morgan 2007) and, in turn, the culture of practice itself (Padfield and Maruna, 2006). Wider cultural shifts influencing Scottish criminal justice social work practice in the move away from a welfare-oriented approach to one focused on public protection and offender management have been discussed elsewhere (see McNeill and Whyte 2007; Croall et al., 2010). Incrementally, this has heralded the emergence of a system of differential justice in relation to specific categories of offender and of shifts in conceptions of offender by offence type, as well as a shift in sentencing and offender management on the basis of the perceived 'riskiness' of the individual offender in terms of what they might do as opposed to simply what they have done (Weaver and McNeill 2010). However, it may be that the influence of wider cultural shifts, mirrored in shifts in the rhetoric of official discourses on the purposes of community-based supervision have been met by a level of 'ideological co-optation' in criminal justice social work practice, in that workers may be tending to identify with official discourses surrounding risk and protection, (McNeill et al., 2009: 294; see also Robinson and McNeill 2004), although there is also evidence internationally and in Scotland of a degree of resistance, and mediation of risk assessment policy into actual practices (eg Field and Nelken 2010; Tata et al.,2008; McNeill et al., 2009; Beyens and Scheirs 2010). This can, at least in part, be ascribed to the utility of discourses of risk and protection as mechanisms for relegitimating existing practices in new ways, not least, in some cases, in response to a self conscious awareness of the "gaze' of the external audience" (Robinson and McNeill 2004: 293) but more generally, in the context of an increasing loss of faith, credibility and legitimacy in traditional penal welfarist aims amongst the stakeholders, or 'consumers' of criminal justice social work services (McCulloch and McNeill 2007: 223). Risk assessment in criminal justice not only informs the initial sentence and intervention, but also informs 'enforcement decision making and can provide the basis for expedited enforcement action' (Ugwudike, 2011: 243). However, risk assessment is far from accurate, often overrating the risk of reoffending and confusing criminogenic and non- 
Peer Reviewed, pre-proof, pre-publication draft version. Subsequently published in The European Journal of Probation 2012 4(1): 84-98.

criminogenic needs (eg Hannah-Moffat and Maurutto 2010), notably amongst women offenders (McIvor and Kemshall, 2002; Barry and McIvor, 2010), and we return to this topic in the following section.

While the shift towards risk aversion in criminal justice has noticeably influenced enforcement practices, the importation of actuarial and augmentative technologies of risk assessment, control and surveillance, of progressively restrictive and numerous licence conditions, plus the creation of civil orders, may have heralded a change in social workers' thresholds of tolerance towards noncompliance, particularly with high risk or serious offenders, where the risk of harm posed to the public is seen as significant (Robinson and McNeill 2004). Padfield and Maruna (2006: 338), citing Nellis and Chui (2003), argue that 'the increase in multi-agency work, in particular partnership work with the police, has sharply improved the surveillance capabilities of traditional aftercare'. These dynamics not only increase capacities to identify incidences of non-compliance but by ratcheting up restrictions, increase the potential for non-compliance. Relatedly, closer working alliances between these agencies, not least in the form of Multi-Agency Public Protection Arrangements (MAPPA), may have conceivably encouraged a possible cross-fertilization, or 'cultural transference' (Nash and Walker 2009) of professional ideologies and objectives contributing to increasingly risk averse, if not pre-emptive practices, as a consequence of reduced tolerance thresholds for non-compliance. Reduced tolerance thresholds are undoubtedly underpinned by fears surrounding organisational credibility and legitimacy, particularly in the wake of occasional, highly publicised and disturbing crimes (Weaver and McNeill 2010). Under the pressures of a risk averse society and its attendant 'blame culture', there are anecdotal reports of practitioners reverting to 'constructive breach' or 'preemptive enforcement'; in other words, in cases where released offenders pose very serious concerns, the temptation is to load licences with untenable conditions in order to precipitate breach and recall to custody (Nellis 1999; McNeill 2009a). That said, we are not suggesting that the 
evident radical changes in policy and official discourses are simply and neatly transferred into actual practices on the ground. Closer empirical analysis is needed and this may well suggest a picture which is characterized by a degree of resistance (whether deliberate or not) of major policy and ideological shifts whereby 'old' and 'new' may synergise in unexpected ways (e.g. Beyens and Scheirs 2010; Field and Nelken 2010; McNeill et al., 2009; Tata et al., 2008).

\section{Social worker discretion and offender rehabilitation}

Not only has there been a shift in the regulation of offender compliance but the use of professional judgment and discretion has been increasingly constrained by shifts in the regulation and governance of practice (Phillips 2011). Kemshall (2003: 27) identifies a number of broad trends in the 'new penality' (see also Feeley and Simon, 1992), including the replacement of clinical and professional judgement with standardised, actuarial risk assessment instruments, the use of multiagency approaches in the administration of criminal justice policy and practice, often associated with techniques of accountability; a rise in managerialism characteristic of wider public service reform, and the use of audit, performance indicators, and the economic language of 'best value'. Managerialism and the associated emphasis on individual and organisational accountability has, arguably, continued to erode the autonomy of professionals, or at least their desire to liberally exercise discretion, and this may account for a more risk averse stance towards enforcement and a culture of reduced tolerance towards non-compliance (Padfield and Maruna 2006; Phillips 2011). In this vein, Phillips (2011) suggests that perceptions of accountability are increasingly directed upwards, in relation to their obligations to the courts, or to the government, or outwards in relation to the public who have been recast as beneficiaries of the system (McCulloch and McNeill 2007), and less often, downwards, towards the offender. This is underlined in the NOS (Scottish Government 2004) which remind social workers that they work 'on behalf of the Secretary of State, to help to protect the community against social harm' (Scottish Government 2004: paragraph 235). 
Peer Reviewed, pre-proof, pre-publication draft version. Subsequently published in The European Journal of Probation 2012 4(1): 84-98.

This can serve to mitigate against the more constructive policy and practice objectives of 'offender engagement' (Robinson and McNeill 2008; Padfield and Maruna 2006; Phillips 2011), or at least send out mixed signals and lead to disparities in the use of discretion.

Discretion does not apply in the case of further alleged offending, where immediate notification to the Justice Department of the Scottish Government is mandatory - in other words, if the social worker is aware that a licensee is charged with a further offence during the licence period. By contrast, reporting of breach of any other requirements of the licence (e.g., failure to keep appointments) is a matter for the professional judgment of the supervising criminal justice social worker (Scottish Government, 2004). Although immediate revocation of a licence by the Justice Department without reference to the Parole Board is possible in the public interest (sect 17, Prisoners \& Criminal Proceedings (Scotland) Act 1993), it is more usual for the matter to be referred to the Board for decision. The seriousness of a failure to comply is to be judged in terms of matters such as the nature of the breach, the point in the licence at which this happens (the presumption being that an early breach is more likely to be acted upon), the attitude of the offender towards observing and complying with the licence, the level of risk posed and other background circumstances relating to community re-settlement. In the case of what are considered by supervising social workers to be 'unacceptable' failures to comply with requirements, up to two formal warnings should be issued before invoking recall procedures. Revocation of a licence results in a return to prison, although this may be challenged at an oral hearing convened by the Parole Board (Scottish Government, 2004).

In this manner, the NOS to a greater or lesser degree govern the exercise of discretion over the regulation of offender compliance in Scotland. In turn, social work compliance with the NOS informs inspections and assessments of performance undertaken by the Social Work Inspection 
Agency (SWIA). While there is no ambiguity that the acquisition of a further charge, and thus the alleged commission of an offence, should immediately be brought to the attention of the Scottish Government, what constitutes non-compliance more generally remains widely open to discretion, informed by the exercise of professional judgment. Yet, according to the Criminal Justice Social Work Performance Inspection Programme 2003-2007 (SWIA 2007) there remain disparities both in enforcement practices and in the regulation of those practices across Scotland. In some areas, SWIA found that social work managers were not routinely monitoring enforcement practice and were relying largely on their staff to consult them about enforcement issues. Moreover, social workers seemed to be uncertain about the formal parameters within which they could exercise discretion and frequently used their own judgment. These judgments were usually about whether a particular infringement was 'acceptable' or not, rather than about the risk posed by the offender.

If desistance from offending is a process characterised by indecision and uncertainty (Burnett 1992), and by lapse and relapse (Glaser 1964), how much and how many such lapses and relapses are acceptable? Desistance from offending is generally conceptualized as a process involving an interplay between structure, or external factors, and 'agency', or internal factors. Put simply, structural explanations imply that opportunities such as relationships or employment encourage reduced offending, and agentic explanations imply that individuals consciously choose to desist from crime through a change in attitude or behaviour. Whilst much criminal justice policy in recent decades has focused almost entirely on agency - the choices made by individuals who wish to offend or re-offend, little focus has been placed on structure - the options available to individuals who wish not to offend. The structure-agency debate in criminology is no more apparent than in the differing views of offenders and policy makers about what encourages desistance. Offenders stress structural opportunities, whilst policy makers stress the responsibilisation and changed attitudes of the offender (Barry, 2006a). Recall policy merely addresses the views of policy makers (the responsibilisation thesis) but neglects to address the structural constraints placed on offenders on 
Peer Reviewed, pre-proof, pre-publication draft version. Subsequently published in The European Journal of Probation 2012 4(1): 84-98.

release from prison. Throughcare (i.e., the provision of services to individuals during and after a period of custody) is thus essential, not only for rehabilitation but also to prevent breach and recall.

All released prisoners need support on the outside to ensure that their intended changes in attitude and behaviour are sustainable. And yet, throughcare has a bad press, being seen in criminal justice circles in Scotland as the Cinderella service (Scottish Government, 2003). In particular, women tend to receive shorter prison sentences (Barry and McIvor, 2010), thereby making them ineligible for parole or throughcare. Shorter prison sentences also mean that women cannot be included in prisonbased programmes which are aimed at, and timetabled for, longer-term prisoners, thus denying many women that particular opportunity not only to access support to modify their behaviour but also to prove their worth with prison staff (who write reports to parole boards) and the Parole Board itself (Hannah-Moffat and Yule, 2011). It is perhaps worth noting that Parole Board reports in Scotland do not disaggregate gender data and these figures were not available to the researchers on request. However, Hannah-Moffat and Yule (2011) suggest that Parole Board members in Canada specifically take into account the duration of criminal careers and prison sentences, the seriousness of the current offence and expressions of remorse, and that women tend to come out better than men in these respects. Indeed, these authors suggest that seriousness of the current offence and criminal career are unrelated to parole board decision making. Decisions tend to be made based on current (at the time of parole application) propensity to change and to reduced criminogenic need.

In Scotland, women comprise approximately 16 per cent of those prosecuted, 8 per cent of those imprisoned, 23 per cent of those given DTTOs and 18 per cent of those on probation (Malloch and McIvor, 2011), and yet it is increasingly apparent that both prison and community-based disposals are not necessarily women-friendly (Barry \& McIvor, 2010; Malloch and McIvor, 2011). Women are also more likely than men to breach community-based disposals because of an inability to 
comply rather than because of further offending (Barry and McIvor, 2010). Women find it difficult to attend appointments (not least with several criminal justice agencies concurrently), have childcare commitments which preclude certain community-based disposals, cannot afford to travel to and from often centrally-located social work departments, and may fear meeting old 'associates' or abusive ex-partners whilst attending social work departments (Malloch and McIvor, 2011).

Offenders often suggest that better 'mainstream' opportunities and more constructive advice on their practical needs would go a long way towards alleviating problems, establishing stability and thereby encouraging desistance (Barry, 2006a). Desistance literature has stressed the importance of the worker-client relationship, not least in offering positive reinforcement, role models and motivation to change (McNeill, 2006, 2009b). McNeill (2009b: 148) suggests that: 'supporting desistance requires supervisors to demonstrate optimism, hopefulness, patience, persistence, fairness, respectfulness, trustworthiness'. In tandem with a meaningful relationship, there is the need for equally meaningful interventions that 'fit' the client. This reflects the 'responsivity' principle of the What Works? literature, which in turn feeds into compliance rates. As Ugwudike (2011) suggests, fairness and legitimacy in the supervisory relationship encourages compliance, and barriers to compliance need to be overcome through supervision that is responsive to the wider issues affecting offenders. In two studies of the views of offending and desistance amongst young people aged 13-33 (Barry, 2006b; Cruickshank and Barry, 2008), it was found that three particular interventions were the most promising in terms of encouraging desistance:

- $\quad$ offering constructive activities and practical advice for clients about employment, housing and relationships, rather than focusing on offending behaviour in a vacuum;

- $\quad$ listening to clients about their hopes and fears and encouraging a strong and genuine worker-client relationship; 
Peer Reviewed, pre-proof, pre-publication draft version. Subsequently published in The European Journal of Probation 2012 4(1): 84-98.

- $\quad$ developing meaningful interventions that are tailor-made to fit the needs and circumstances of individual clients.

However, as previously inferred, it is not only the actual one-to-one relationships between supervisor and client that is important in influencing whether or not an offender complies with conditions of a court order. The other crucial factor is risk and it is feared by many commentators that a preoccupation with risk is increasingly superseding the therapeutic relationship in the race to satisfy the needs of an effective and efficient supervisory regime in a bid to secure external credibility and legitimacy (see, for example, Robinson and McNeill 2008).

\section{Conclusions}

This article has sought to argue that recall policy and practice should no longer be seen as a discrete technical corner of the justice system, but rather they should be understood as a consequence of the political failure to address rising levels of 'front door' entry into prison. Reducing potentially spiralling recall rates may well depend on the ability of policy makers and indeed sentencers to deal with that 'front door' issue. Equally, back door re-sentencing and the re-imprisoning of offenders following breach of overly onerous conditions, whilst disrupting any ongoing and promising interventions with those individuals in the community, will only serve to prolong the revolving prison door syndrome.

Nonetheless, the rise in recall rates shows no signs of abating, but as we have attempted to illustrate, not only are explanations for this phenomenon complex and multi-faceted but the implications are far-reaching, not only for offenders but also for the public, politicians, sentencers and prison managers. Arguing for holistic thinking about compliance, Bottoms (2001: 112) has argued against 
'exclusive reliance on constraint-based compliance' (emphasis in original). Instead he stresses the 'need to think constructively about integrated penalty "packages" that will attempt to enhance compliance through a creative mixture of constraint-based, instrumental, normative and habitual mechanisms' (ibid: 112). If, as Robinson and McNeill (2008) suggest, sentencing practices and the administration of those sentences are to secure both external legitimacy (with wider stakeholders) and internal legitimacy with individual offenders and their supervising officers, this hitherto comparatively neglected and relatively covert practice merits greater attention.

\section{References}

Anderson, S., D. Ingram and N. Hutton (2002) Public attitudes towards sentencing and alternatives to imprisonment. Scottish Parliament Paper 488 session 1 2002. Edinburgh: HMSO.

Arnott, H. (2007) 'Recalls: contested facts and risk assessment' in N. Padfield (Ed.) Who to Release, (pp 173-190). Cullompton: Willan.

Ashworth, A. (2005) Sentencing and Criminal Justice Cambridge: Cambridge University Press.

Barry, M. (2006a) 'Dispensing [with?] Justice: Young people's views of the criminal justice system', in K. Gorman, M. Gregory, M. Hayles and N. Parton (eds) Constructive Work with Offenders, London: Jessica Kingsley, pp. 177-192.

Barry, M. (2006b) Youth Offending in Transition: The search for social recognition, Abingdon: Routledge. 
Peer Reviewed, pre-proof, pre-publication draft version. Subsequently published in The European Journal of Probation 2012 4(1): 84-98.

Barry, M. and McIvor, G. (2010) 'Professional decision making and women offenders: containing the chaos?'Probation Journal 57 (1): 27-42.

Beyens, K. and V. Scheirs (2010) 'Encounters of a Different Kind: Social Enquiry and Sentencing in Belgium’ Punishment \& Society 12 (3):309-328

Bottoms, A. (2001) 'Compliance and Community Penalities’ in A.Bottoms, L. Gelsthorpe, S. Rex (eds) Community Penalties: change and challenges Willan 87-117

Burnett, R. (1992) The Dynamics of Recidivism, Oxford: Centre for Criminological Research, University of Oxford.

Cavadino, M. and Dignan, J (2006) Penal Systems: A comparative approach, London: Sage.

Croall H, Mooney G, Munro M (2010) Criminal Justice in Scotland - Willan Publishing

Cruickshank, C-A. and Barry, M. (2008) 'Nothing has convinced me to stop': Young people's perceptions and experiences of persistent offending, Glasgow: Who Cares? Scotland.

Feeley, M. and Simon, J. (1992) 'The New Penology: Notes on the emerging strategy of corrections and its implications', Criminology, 30: 4: 449-74.

Field, S. and D. Nelken (2010) 'Reading and Writing Youth Justice in Italy and England and Wales' Punishment \& Society 12(3): 287-308 
Glaser D (1964) Effectiveness of a Prison and Parole System. Indianapolis, IN Bobbs-Merrill,

Hannah-Moffat, K and Maurutto, P. (2010) 'Re-contextualising pre-sentence reports: risk and race' Punishment \& Society 12(3) 262-286

Hannah-Moffat, K. and Yule, C. (2011) 'Gaining insight, changing attitudes and managing 'risk': Parole release decisions for women convicted of violent crimes', Punishment and Society, 13 (2): 149-175.

Kemshall, H. (2003) Understanding Risk in Criminal Justice: Buckingham: OUP

Kemshall, H. and Wood, J. (2007) 'High Risk Offenders and Public Protection' in L. Gelsthorpe and R. Morgan (Eds), Handbook of Probation (pp 381-397), London: Willan.

Kincraig Committee (1989) Parole and Related Issues in Scotland, Edinburgh: Scottish Office.

Malloch, M. and McIvor, G. (2011) 'Women and Community Sentences', Criminology and Criminal Justice, 11 (4): 325-344.

McCulloch, P. and McNeill, F. (2007) 'Consumer Society, Commodification and Offender Management'. Criminology and Criminal Justice 7 (3): 223-42

McIvor, G. and Barry, M. (2000) Social Work and Criminal Justice: The Longer Term Impact of Supervision, Edinburgh: The Stationery Office. 
Peer Reviewed, pre-proof, pre-publication draft version. Subsequently published in The European Journal of Probation 2012 4(1): 84-98.

McIvor, G. and Kemshall, H. (2002) Serious Violent and Sexual Offenders: The use of risk assessment tools in Scotland, Edinburgh: Scottish Executive Social Research.

McManus, J (1999) 'Imprisonment and Other Custodial Sentences' in P. Duff, and N. Hutton, Criminal Justice in Scotland. London: Ashgate, pp 228 - 242.

McNeill, F. (2009a) 'Young People, Serious Offending and Managing Risk : a Scottish Perspective in Baker, K. and Sutherland, A. Multi-Agency Public Protection Arrangements and Young People. The Policy Press.

McNeill, F. (2009b) ‘Supervising Young Offenders: What Works and What's Right', in M. Barry and F. McNeill (eds) Youth Offending and Youth Justice, London: Jessica Kingsley, pp. 132-153).

McNeill, F. (2006) 'A desistance paradigm for offender management', Criminology and Criminal Justice, 6: 39-62.

McNeill, F. (2004) 'Desistance, Rehabilitation and Correctionalism: Developments and Prospects in Scotland', Howard Journal, 43 (4): 420-436.

McNeill, F., Burns, N., Halliday, S., Hutton, N., and Tata, C. (2009) 'Risk, Responsibility and Reconfiguration' Punishment and Society 11 (4): 419-442.

McNeill F and Whyte B (2007) Reducing Re-Offending - Social work and Criminal Justice in Scotland. Willan Publishing 
Morgan, R. (2007) 'Probation, Governance and Accountability', in L. Gelsthorpe and R. Morgan (Eds) Handbook of Probation (pp90-113). Cullompton: Willan Publishing.

Nash, M., and Walker, L. (2009) MAPPA - Is closer collaboration really the key to effectiveness? Policing 3 (2): 172-80

Nellis, M. (1999) 'Towards "the Field of Corrections": Modernizing the Probation Service in the Late 1990s', Social Policy and Administration 33: 302-23.

Nellis, M. and W.H. Chui (eds) (2003) Moving Probation Forward: Evidence, Arguments and Practice. Harlow: Longman/Pearson Education.

Padfield, N. and S. Maruna (2006) 'The Revolving Door at the Prison Gate: exploring the dramatic increase in recalls to prison' Theoretical Criminology 6(3): 329-352

Parole Board for Scotland (series from 2003) Annual Reports.

http://www.scottishparoleboard.gov.uk/documents.asp

Phillips, J. (2011) Target, audit and risk assessment cultures in the probation service. European Journal of Probation, 3 (3): 108-122

Roberts, J and M. Hough (2005) Understanding Public Attitudes to Criminal Justice Open University Press

Robinson, G and McNeill, F (2008) Exploring the dynamics of compliance with community penalties. Theoretical Criminology. 12 (4): 431-449. 
Peer Reviewed, pre-proof, pre-publication draft version. Subsequently published in The European Journal of Probation 2012 4(1): 84-98.

Robinson, G. and McNeill, F. (2004) 'Purposes Matters: Examining the Ends of Probation', in G. Mair (ed.) What Matters in Probation Work. Cullompton: Willan. pp. 277-304.

Scottish Consortium on Crime and Criminal Justice and Scottish Centre for Crime and Justice Research (2009). Report of seminar on recall to custody held on 24th April 2009.

http://www.scccj.org.uk/index.php/scccj-publications/

Scottish Government (2003) Report of the Tripartite Group on Throughcare Issues, Edinburgh: Scottish Government.

Scottish Government (2004) National Objectives for Social Work Services in the Criminal Justice System: Standards Throughcare, Edinburgh: Scottish Government.

Scottish Government (2011) Prison statistics Scotland 2010-11.

http://www.scotland.gov.uk/Publications/2011/08/19154230/0

Scottish Prisons Commission (2008) Scotland's Choice, Edinburgh: Scottish Prisons Commission.

Social Work Inspection Agency (2007) Criminal justice social work inspection programme 2003 2007 - final report available online at:

http://www.scotland.gov.uk/Publications/2007/10/23113246/0 
Tata, C. (2010) 'Sentencing and Penal Decision-Making: Is Scotland Losing its Distinctiveness? In H. Croall, G. Mooney and M. Munro (Eds) Criminal Justice in Scotland (pp 195-215) Willan/Routledge

Tata, C. and D. Thomson (2011) 'Sentencing and Release from Prison' Scolag. Scottish Legal Action Group Legal Journal Issue. March 2011 Issue 401, 57

Tata, C., Halliday, S., Hutton, N., McNeill, F. (2008) 'Advising and Assisting the Sentencing Decision Process: the Pursuit of 'Quality' in Pre-Sentence Reports' British Journal of Criminology 48: $835-855$

Thomson, D. (2007) Prisons, Prisoners and Parole Thomson W. Green Thomson, D. (2010) 'Scotland', in N. Padfield, D van Zyl Smit and F. Dunkel (Eds), Release from Prison: European policy and practice, (pp316-336). Cullompton: Willan.

Ugwudike, P. (2011) 'Mapping the interface between contemporary risk-focused policy and frontline enforcement practice', Criminology and Criminal Justice, 11 (3): 242-258.

Weaver, B., and McNeill, N (2010) 'Public Protection in Scotland: A Way Forward?' in Nash M, and Williams A (Eds) Handbook of Public Protection (pp 272-294). Willan Publishing. 